\title{
REGIONAL DEVELOPMENT AND COHESION POLICY OF EU 2021-2027
}

\author{
E. Mutafov* \\ Faculty of Economics, Trakia Univesity, Stara Zagora, Bulgaria
}

\begin{abstract}
Cohesion policy is the EU's main investment policy and one of the most specific expressions of solidarity. Further investment is needed to overcome the persisting differences between Member States. After 2020, resource allocation to the regions will continue and the greatest efforts will be needed to bring these countries together with the rest of the EU. At the same time, cohesion policy will continue to play the role of a strong and direct link between the EU and its regions and cities. The main purpose of this article is to compare the approaches in allocating funds across the different EU Member States and how the implemented Cohesion Policy will change after the year of 2020.
\end{abstract}

Key words: Regional policy, Budget of EU

\section{INTRODUCTION}

Most of the EU funding is channeled through the 5 European structural and investment funds (ESIF), which are managed by the European Commission and the EU countries. The purpose of all these funds is to invest in sustainable and healthy European economy and environment. There are different areas where the funding is focused: research and innovation, digital technologies, sustainable management of natural resources, small businesses etc.

Back in the years with the joining of Bulgaria to the European Union (year of 2007), there are 3 funds that are operational continuously until today in order to help reducing the economic disparities between the regions of the European countries. They are:

- European regional development fund (ERDF)

- European social fund (ESF)

- Cohesion fund (CF)

Each fund is having different scope of support, however they all are investing the first and

\footnotetext{
*Correspondence to: Emil Mutafov, Faculty of Economics, Trakia Univesity, Stara Zagora, Bulgaria, e-mail: mutafov@uni-sz.bg tel. +359888 949174.
}

most important goal of the European Union e.g. "Convergence". The level of support and source of funding depends on each region's position and relation to the average GDP per capita of the EU-28. They are:

- Less developed regions: When GDP per capita is less than $75 \%$ of the average GDP of the EU-28;

- Transition regions: When GDP per capita is between $75 \%$ and $90 \%$ of the average GDP of the EU-28- this category replaced the phasing-in and phasing-out mechanisms applied in 2007-2013 funding period;

- More developed regions: When GDP per capita is above $90 \%$ of the average GDP of the EU-28.

\section{CURRENT STATUS ACCORDING THE STRATEGY EUROPE 2020}

The integration of the countries of South Eastern Europe into the European open market is a major reason for increasing their regional disparities and affects mostly those with weaker economies (1). At the moment there are five main goals according the Europe 2020 strategy and they are covered to some level. Reviewing the progress in the different goals may show the level or participation for each country and their economic stability. Here is how we can sum up the progress so far: 
Table 1. Strategy "Europe 2020" - goals and progress until year $2018 / \%$

\begin{tabular}{|c|c|c|c|c|c|c|c|c|c|}
\hline \multirow[b]{3}{*}{ COUNTRY } & \multicolumn{9}{|c|}{$\begin{array}{l}\text { STRATEGY EUROPE } 2020 \text { - GOALS AND PROGRESS UNTIL YEAR } 2018 \\
/ \%\end{array}$} \\
\hline & \multicolumn{2}{|c|}{$\begin{array}{l}\text { Employment } \\
\text { rate }\end{array}$} & \multicolumn{2}{|c|}{$\begin{array}{l}\text { Research and } \\
\text { Development }\end{array}$} & \multicolumn{2}{|c|}{$\begin{array}{c}\text { Renewable } \\
\text { energy } \\
\text { consumption }\end{array}$} & \multicolumn{2}{|c|}{$\begin{array}{c}\text { Education / } \\
\text { University } \\
\text { degree }\end{array}$} & \multirow{2}{*}{$\begin{array}{c}\text { People at } \\
\text { risk of } \\
\text { poverty } \\
2018\end{array}$} \\
\hline & 2018 & TARGET & 2018 & TARGET & 2018 & TARGET & 2018 & TARGET & \\
\hline EU - 28 & 73,20 & 75,00 & 2,06 & 3,00 & 17,52 & 20,00 & 40,70 & 40,00 & \\
\hline Belgium & 69,70 & 73,20 & 2,58 & 3,00 & 9,06 & 13,00 & 47,60 & 47,00 & 16,40 \\
\hline Bulgaria & 72,40 & 76,00 & 0,75 & 1,50 & 18,73 & 16,00 & 33,70 & 36,00 & 22,00 \\
\hline Czechia & 79,90 & 75,00 & 1,79 & 1,00 & 14,76 & 13,00 & 33,70 & 32,00 & 9,60 \\
\hline Denmark & 78,20 & 80,00 & 3,05 & 3,00 & 35,77 & 30,00 & 49,10 & 40,00 & 12,80 \\
\hline Germany & 79,90 & 77,00 & 3,02 & 3,00 & 15,45 & 18,00 & 34,90 & 42,00 & : \\
\hline Estonia & 79,50 & 76,00 & 1,29 & 3,00 & 29,21 & 25,00 & 47,20 & 40,00 & 21,90 \\
\hline Ireland & 74,10 & 69,00 & 1,05 & 2,00 & 10,65 & 16,00 & 56,30 & 60,00 & : \\
\hline Greece & 59,50 & 70,00 & 1,13 & 1,20 & 16,32 & 18,00 & 44,30 & 32,00 & 18,50 \\
\hline Spain & 67,00 & 74,00 & 1,20 & 2,00 & 17,51 & 20,00 & 42,40 & 44,00 & 21,50 \\
\hline France & 71,30 & 75,00 & 2,19 & 3,00 & 16,30 & 23,00 & 46,20 & 50,00 & : \\
\hline Croatia & 65,20 & 62,90 & 0,86 & 1,40 & 27,28 & 20,00 & 34,10 & 35,00 & 19,40 \\
\hline Italy & 63,00 & 67,00 & 1,35 & 1,53 & 18,27 & 17,00 & 27,80 & 26,00 & : \\
\hline Cyprus & 73,90 & 75,00 & 0,56 & 0,50 & 9,85 & 13,00 & 57,10 & 46,00 & : \\
\hline Latvia & 76,80 & 73,00 & 0,51 & 1,50 & 39,01 & 40,00 & 42,70 & 34,00 & 23,30 \\
\hline Lithuania & 77,80 & 72,80 & 0,89 & 1,90 & 25,84 & 23,00 & 57,60 & 48,70 & : \\
\hline Luxembourg & 72,10 & 73,00 & 1,26 & 2,30 & 6,38 & 11,00 & 56,20 & 66,00 & : \\
\hline Hungary & 74,40 & 75,00 & 1,35 & 1,80 & 13,34 & 13,00 & 33,70 & 34,00 & 12,80 \\
\hline Malta & 75,00 & 70,00 & 0,54 & 2,00 & 7,17 & 10,00 & 34,20 & 33,00 & 16,80 \\
\hline Netherlands & 79,20 & 80,00 & 1,99 & 2,50 & 6,60 & 14,00 & 49,40 & 40,00 & 13,40 \\
\hline Austria & 76,20 & 77,00 & 3,16 & 3,76 & 32,56 & 34,00 & 40,70 & 38,00 & 14,30 \\
\hline Poland & 72,20 & 71,00 & 1,03 & 1,70 & 10,90 & 15,00 & 45,70 & 45,00 & $:$ \\
\hline Portugal & 75,40 & 75,00 & 1,33 & 2,70 & 28,12 & 31,00 & 33,50 & 40,00 & 17,30 \\
\hline Romania & 69,90 & 70,00 & 0,50 & 2,00 & 24,47 & 24,00 & 24,60 & 26,70 & 23,50 \\
\hline Slovenia & 75,40 & 75,00 & 1,86 & 3,00 & 21,55 & 25,00 & 42,70 & 40,00 & 13,30 \\
\hline Slovakia & 72,40 & 72,00 & 0,88 & 1,20 & 11,49 & 14,00 & 37,70 & 40,00 & $:$ \\
\hline Finland & 76,30 & 78,00 & 2,76 & 4,00 & 41,01 & 38,00 & 44,20 & 42,00 & 12,00 \\
\hline Sweden & 82,60 & 80,00 & 3,40 & 4,00 & 54,50 & 49,00 & 52,00 & 45,00 & 16,40 \\
\hline $\begin{array}{c}\text { United } \\
\text { Kingdom }\end{array}$ & 78,70 & : & 1,66 & : & 10,21 & 15,00 & 48,80 & : & : \\
\hline
\end{tabular}

Source: Statistical book: Smarter, greener, more inclusive? Indicators to support the Europe 2020 strategy, 2018 edition, p. 9

According the information in Table $\mathbf{1}$ we monitor the next changes for the different goal as follows:

- $\quad$ Employment rate - we know the main goal for EU is $75 \%$ and Bulgaria as part of the union is aiming to reach $76 \%$ employment rate. So far we see $72.40 \%$ measured in 2018 , however the remaining 3.6 $\%$ may not be easy task regarding the past experience and no higher results than $70 \%$ (in 2008 ) in the last 15 years.

Research and development comprehensibly, taking into consideration the investments in the research and innovations for the past years, Bulgarian final goal for year 2020 is $1.5 \%$ from GDP. Sadly this goal does not look possible to reach as we see result of $0.75 \%$ for the last year which is the greatest result at all, since the country is part of EU; 
MUTAFOV E.

- Renewable energy consumption - the very strange fact here is that we placed goal that we already reached before the period 2014-2020 even started. Bulgaria is having already more than $16 \%$ energy produced by renewable sources and what is making impression is the lack of growth in this period;

Education - the goal here is looking really possible to be completed and achieved in the year 2020. We can have $36 \%$ of the population between 30-34 years old graduated high school.
- $\quad$ People at risk of poverty - for year 2018, statistics are saying that there are 5 countries (incl. Bulgaria) with high risk with more than $20 \%$ of the population in this category and 4 more with results really close to the same level of risk.

Another very important factor that needs to be reviewed is the GDP by country. Considering the progress of the Strategy Europe 2020 here is how we can summarize the change in the GDP per capita year 2014 when the strategy was broad to our attention and the strategy period started.

Table 2. GDP per capita 2014-2018 /\%

\begin{tabular}{|l|c|c|c|c|c|}
\hline \multicolumn{5}{|c|}{ GDP PER CAPITA / 2014-2018, \% } \\
\hline Country & $\mathbf{2 0 1 4}$ & $\mathbf{2 0 1 5}$ & $\mathbf{2 0 1 6}$ & $\mathbf{2 0 1 7}$ & $\mathbf{2 0 1 8}$ \\
\hline EU - 28 countries & 100 & 100 & 100 & 100 & 100 \\
\hline Belgium & 119 & 118 & 118 & 116 & 115 \\
\hline Bulgaria & 47 & 47 & 48 & 49 & 50 \\
\hline Czechia & 86 & 87 & 88 & 89 & 90 \\
\hline Denmark & 128 & 127 & 126 & 128 & 126 \\
\hline Germany & 126 & 124 & 124 & 124 & 123 \\
\hline Estonia & 77 & 76 & 77 & 79 & 81 \\
\hline Ireland & 136 & 178 & 177 & 181 & 187 \\
\hline Greece & 71 & 69 & 68 & 67 & 68 \\
\hline Spain & 90 & 91 & 91 & 92 & 91 \\
\hline France & 107 & 106 & 104 & 104 & 104 \\
\hline Croatia & 59 & 59 & 61 & 62 & 63 \\
\hline Italy & 96 & 95 & 97 & 96 & 95 \\
\hline Cyprus & 81 & 82 & 84 & 85 & 87 \\
\hline Latvia & 63 & 64 & 64 & 67 & 70 \\
\hline Lithuania & 75 & 75 & 75 & 78 & 81 \\
\hline Luxembourg & 269 & 266 & 260 & 253 & 254 \\
\hline Hungary & 68 & 68 & 67 & 68 & 70 \\
\hline Malta & 89 & 93 & 95 & 98 & 98 \\
\hline Netherlands & 131 & 130 & 128 & 128 & 129 \\
\hline Austria & 130 & 129 & 128 & 127 & 127 \\
\hline Poland & 67 & 69 & 68 & 70 & 71 \\
\hline Portugal & 77 & 77 & 77 & 77 & 76 \\
\hline Romania & 55 & 56 & 59 & 63 & 64 \\
\hline Slovenia & 82 & 82 & 83 & 85 & 87 \\
\hline Slovakia & 77 & 77 & 77 & 76 & 78 \\
\hline Finland & 110 & 109 & 109 & 109 & 110 \\
\hline Sweden & 124 & 125 & 122 & 121 & 121 \\
\hline United Kingdom & 109 & 109 & 107 & 106 & 104 \\
\hline Sour: Em & & & & & \\
\hline
\end{tabular}

Source: Eurostat

As additional description we have to clarify that Gross domestic product (GDP) is a measure for the economic activity which is defined as the value of all goods and services produced less the value of any goods or services used in their creation. The volume index of GDP per capita in Purchasing Power Standards (PPS) is expressed in relation to the European Union (EU28) average set to equal 100. If the index of a country is higher than 100 , this country's level of GDP per head is higher than the EU average and vice versa.
Although the visible progress for Bulgaria, we can still see it takes last place in EU chart by GDP per capita (Table 2) and change in the last 5 years with $3 \%$ increase compared to Romania (increase with $9 \%$ for the same period) this is 3 times lower result. Even Croatia, joined EU in 2013, has better statistics when we compare years 2014 and 2018.

\section{WHAT IS YET TO COME IN REGARDS OF THE COHESION POLICY 2021-2027}

Regions that are still lagging behind in terms of growth or income (mostly located in the South 


\section{MUTAFOV E.}

and East of Europe) will keep benefiting from the EU funds. Cohesion Policy will be well balanced and will still continue investing in all regions, including in richer Member States struggling to achieve industrial transition and fight unemployment.

A tailored approach: Cohesion Policy keeps 3 categories of regions: less-developed, transition and more developed regions. To reduce disparities and help low-income and low-growth regions catch up, GDP per capita remains the predominant criterion for allocating funds. In addition, new criteria aim at better reflecting the reality on the ground - youth unemployment, low education level, climate change and the reception and integration of migrants.

In details the new changes will be applied on a way to deliver more simplifications with the new Cohesion policy rulebook (CPR).

We can describe the changes in different aspects as follows:

- From legal point of view

- $\quad$ All 7 shared management funds will be covered in a single framework. This rulebook aims to provide aligned implementation rules for all funds and additionally simplify the documentation;

- There will be merging of 3 funds to create ESF+. This means the ERDF, ESF and CF will be combined in ESF+ which will result in increased visibility and readability of EU. It will also bring facilitate combination of social inclusion;

- $\quad$ The number of empowerments will drop significantly. We have for the period 2014-2020 about 50 empowerments and they will drop to only 9 in the period 2021-2027.

- Conditions, programming and policy framework

- There are 11 thematic objectives for period 2014-2020. They will be consolidated into 5 policy objectives after 2021. Broader policy objectives are simpler for reporting and allow Member States to be more flexible in shifting funds within a priority.

- 20 conditions instead of almost 40 in 2014-2020 - Conditions are tightly focused on the policy areas with the most impact on the effectiveness of cohesion policy.

- There will be no longer Common Strategic Framework, which means one less layer in the programming.

- No more changes of the partnership agreement after initial adoption - in the period $2014-2020$ it is obligatory to apply all changes in the agreement. From 2021 that won't be necessary anymore and that is one administrative burden less that will make the process of funding simple enough.

- There will be one single audit arrangement - Commission will audit only the audit authority if its opinion is reliable and the Member State is part of the collaboration with the European Public Prosecutor's Office. ERDF and Cohesion Fund projects below EUR 400.000 eligible cost and ESF projects below EUR 300.000 will be audited once only prior to completion. Other projects only once per accounting year. (2)

\section{CONCLUSIONS}

The new period starting from 2021 can offer absolutely renovated and easily managing programming regarding all funding and procedures of applying. Certainly the new regional and cohesion policy will continue to invest in all different regions as they will keep the main goal untouched e.g. minimizing the interregional disparities and equalize the standard in all regions in EU. There will be five main goals for the period $2021-2027$ and they will increase the chance for successful results. Regional policy will focus in the next areas: smarter Europe, Greener and carbon free Europe, Connected Europe, with strategic transport and digital networks, social Europe and Europe closer to citizens, by supporting sustainable urban development. Investments in the above mentioned areas may lead EU to brighter future for all member states.

In order to achieve the desired results and according the changes in the European Cohesion policy, the next recommendations may be drawn - 1. Europe has to be closer to the citizens and explain better the positive results of Cohesion policy; 2.Member States and regions to raise their communication requirements, such as organizing events for launching large EU-funded projects and developing social media plans. At the same time, projects communication is simplified, with one name covering all different EU funds, a single portal providing information on all available financial means for enterprises, and a single project database managed by the European Commission.

\section{REFERENCES}

1. Totev, S, "Regional disparities in Bulgaria and EU countries" Trakia Journal of Sciences, Vol. 15, Suppl. 1, pp. 5, 2017

2. European Commission, 80 simplification measures in cohesion policy 2021-2027, 2018, https://ec.europa.eu/regional_policy/sources/docg ener/factsheet/new_cp/simplification_handbook_ en.pdf 